\title{
Maturational Patterns of Iodothyronine Phenolic and Tyrosyl Ring Deiodinase Activities in Rat Cerebrum, Cerebellum, and Hypothalamus
}

\author{
Michael M. Kaplan and Kimberlee A. YASKoski, Thyroid Diagnostic Center, \\ Department of Medicine, Brigham and Women's Hospital and \\ Harvard Medical School, Boston, Massachusetts 02115
}

A B S T RACT To explore the control of thyroid hormone metabolism in brain during maturation, we have measured iodothyronine deiodination in homogenates of rat cerebrum, cerebellum, and hypothalamus from $1 \mathrm{~d}$ postnatally through adulthood. Homogenates were incubated with ${ }^{125} I-L-$ thyroxine $\left(\mathrm{T}_{4}\right)+\left[{ }^{131} \mathrm{I}\right] 3,5,3^{\prime}-\mathrm{L}-$ triiodothyronine $\left(\mathrm{T}_{3}\right)+100 \mathrm{mM}$ dithiothreitol. Nonradioactive $T_{4}, T_{3}$, and $3,3^{\prime}, 5^{\prime}$-triiodothyronine $\left(\mathrm{rT}_{3}\right)$ were included, as appropriate. The net production rate of [ $\left.{ }^{125} \mathrm{I}\right] \mathrm{T}_{3}$ from $\mathrm{T}_{4}$ in 1-d cerebral homogenates was similar to the rate in adult cerebral homogenates (9.9 $\pm 2.5[\mathrm{SEM}] \%$ vs. $8.9 \pm 1.2 \% \mathrm{~T}_{4}$ to $\mathrm{T}_{3}$ conversion in $2 \mathrm{~h}$ ). Production of $\mathrm{T}_{3}$ was not detectable in 1-d cerebellar and hypothalamic homogenates. The net $\mathrm{T}_{3}$ production rate in adult cerebellar homogenates was twice as great as, and that in adult hypothalamic homogenates similar to, the rate in cerebral homogenates.

Tyrosyl ring deiodination rates of $T_{4}$ and $T_{3}$ were more than three times as great in cerebral homogenates from 1-d-old rats as in adult cerebral homogenates. In cerebellar homogenates from 1-d-old rats, tyrosyl ring deiodination rates were much greater than the rates in adult cerebellar homogenates, but less than those in 1-d cerebral homogenates. In 1-d hypothalamic homogenates, tyrosyl ring deiodination rates were the highest of all the tissues tested, whereas rates in adult hypothalamic homogenates were similar to those in adult cerebral homogenates.

During maturation, $\mathrm{T}_{4} 5^{\prime}$-deiodination rates increased after $7 \mathrm{~d}$ and exceeded adult rates between 14 and $35 \mathrm{~d}$ in cerebral and cerebellar homogenates, and at 28 and $35 \mathrm{~d}$ in hypothalamic homogenates. In cerebral homogenates, the peak in reaction rate at $28 \mathrm{~d}$ reflected an increase in the maximum enzyme activity

Dr. Kaplan is the recipient of Research Career Development Award 1-KO4-AM 00727-01.

Received for publication 29 August 1980 and in revised form 29 October 1980.
$\left(\mathrm{V}_{\max }\right)$ of the reaction. $\mathrm{T}_{4}$ and $\mathrm{T}_{3}$ tyrosyl ring deiodination rates decreased progressively with age down to adult rates, which were attained at $14 \mathrm{~d}$ for cerebrum and cerebellum and at $28 \mathrm{~d}$ for hypothalamus.

These studies demonstrate quantitative differences in $T_{4} 5^{\prime}$-deiodinase activities in cerebrum, cerebellum, and hypothalamus at all ages, with the overall maturational pattern differing from the developmental patterns of both the pituitary and hepatic $\mathrm{T}_{\mathbf{4}} 5^{\prime}$-deiodinases. Iodothyronine tyrosyl ring deiodinase activities also vary quantitatively among these same brain regions and exhibit a pattern and a time-course of maturation different from that of the $T_{4} 5^{\prime}$-deiodinase. These enzymes could have important roles in the regulation of intracellular $T_{3}$ concentrations and, hence, on the expression of thyroid hormone effects.

\section{INTRODUCTION}

Phenolic ring, or 5'-deiodination of L-thyroxine $\left(T_{4}\right),{ }^{1}$ which occurs in rat brain in vivo (1-3), supplies much of the endogenous $3,5,3^{\prime}$-L-triiodothyronine $\left(\mathrm{T}_{3}\right)$ in the cerebral cortex and cerebellum, including that $T_{3}$ which occupies the nuclear $T_{3}$ binding sites $(2,3)$. After intravenous injection of $\left.{ }^{125} \mathrm{I}_{-} \mathrm{T}_{4},{ }^{125} \mathrm{I}\right] \mathrm{T}_{3}$ is also found in various extranuclear brain fractions, especially the synaptosomal fraction (4), and more ${ }^{125} \mathrm{I}-\mathrm{T}_{3}$ is found in extracts of whole brain tissue and brain nerve cell bodies in 10-d-old rats than in 30-d-old rats (5). Also after intravenous ${ }^{125} \mathrm{I}-\mathrm{T}_{4}$ injection, $\left.{ }^{[25} \mathrm{I}\right] 3,3^{\prime}, 5^{\prime}$-L-triiodothyronine $\left(\mathrm{rT}_{3}\right)$ and a compound that may be $\left[{ }^{125} \mathrm{I}\right] 3,3^{\prime}$ L-diiodothyronine $\left(3,3^{\prime}-\mathrm{T}_{2}\right)$ have been found in rat brain extracts (4). The in vivo occurrence of tyrosyl ring deiodination of $T_{4}$ and $T_{3}$ is thus suggested. We have

${ }^{1}$ Abbreviations used in this paper: DTT, dithiothreitol; $3,3^{\prime}-T_{2}, 3,3^{\prime}$-L-diiodothyronine; $3^{\prime}-T_{1}, 3^{\prime}$-L-iodothyronine; $T_{4}$, L-thyroxine; $\mathrm{T}_{3}, 3,5,3^{\prime}$-L-triiodothyronine; $\mathrm{rT}_{3}, 3,3^{\prime}, 5^{\prime}$-L-triiodothyronine; $V_{\max }$, maximum enzyme activity. 
demonstrated in vitro $\mathrm{T}_{4} 5^{\prime}$-deiodinase activity in homogenates of rat cerebral cortex and cerebellum and found in vitro activity of a separate tyrosyl ring deiodinase that converts $T_{4}$ to $\mathrm{rT}_{3}$ and converts $T_{3}$ sequentially to $3,3^{\prime}-\mathrm{T}_{2}$ and $3^{\prime}$-L-iodothyronine $\left(3^{\prime}-\mathrm{T}_{1}\right)(6)$. Both enzymes are largely particulate and require thiol reducing agents for detectable in vitro activity (6).

Thyroid hormone metabolism in fetal and neonatal rat tissues differs from that in adult tissues. $T_{4} 5^{\prime}$ deiodination rates in liver homogenates from neonates are much lower than in adult liver homogenates, but the differences are abolished by addition of the thiol reducing agent, dithiothreitol (DTT) $(7,8)$. In contrast, in vitro $\mathrm{T}_{4} 5^{\prime}$-deiodination is more rapid in neonatal pituitary tissue than in adult pituitary tissue $(8,9)$. If orderly changes in patterns of thyroid hormone metabolism were also to occur in the brain, then the argument for the biological significance of changes in in vitro rates of iodothyronine deiodination reactions in brain tissue in altered physiological states would be strengthened. Further, since $T_{3}$ is both produced and degraded by brain homogenates, knowledge of relative reaction rates at different ages could facilitate the interpretation of previous (5) and future in vivo studies of brain tissue $\mathrm{T}_{3}$ concentrations. We have therefore investigated changes in deiodinative metabolism of thyroid hormone in vitro occurring during maturation. Cerebrum, cerebellum, and hypothalamus were examined separately, since our previous studies showed differences between adult cerebral cortex and cerebellum in rates of $T_{4} 5^{\prime}$-deiodination and of $T_{4}$ and $T_{3} 5$-deiodination (6). Determinations of the kinetic parameters for $T_{4}$ 5 '-deiodination in cerebral homogenates were also made by modifying the incubation conditions to minimize concomitant reactions that interfere with measurements of $T_{3}$ production.

\section{METHODS}

Nonradioactive iodothyronines were obtained from the Sigma Chemical Co., St. Louis, Mo. and Henning GMBH (Berlin, West Germany). High specific activity tracers were prepared in our laboratory (6). Timed-pregnant Sprague-Dawley rats and adult male Sprague-Dawley rats were supplied by ZivicMiller Laboratories, Allison Park, Pa. Male and female pups were used before age $21 \mathrm{~d}$ and only males were used at older ages. Ages of rats weighing $\geq 200 \mathrm{~g}$ were estimated from their weights according to growth curves from the supplier. Three to four pups (ages $\leq \mathbf{4 3} \mathrm{d}$ ) and three to four adult rats (ages $>60 \mathrm{~d}$ ) were used simultaneously, in anticipation of possible inter-experiment variation. In some experiments two groups of pups and one group of adults were used. Animals were anesthetized lightly with ether and decapitated. Brains were removed to iced $0.05 \mathrm{M}$ Tris, $\mathrm{pH} 7.6-0.25 \mathrm{M}$ sucrose (Trissucrose) and subsequent operations were performed at $0-4^{\circ} \mathrm{C}$. For each group, tissue from the rats was pooled. Brains were divided into cerebellum, hypothalamus, and cerebral hemispheres (with brainstem removed). Whole cerebral hemispheres were used since there was no clear demarcation of the cerebral cortex in 1- and 7-d-old brains. In some experi- ments, adult hypothalami were dissected according to Glowinski and Iversen (10), yielding 90-110 mg tissue per hypothalamus. In other experiments, the cephalad cut was made at the floor of the third ventricle, yielding 30-40 mg tissue per hypothalamus. There was no difference in reaction rates occurring in homogenates of the larger or smaller hypothalamic pieces. Hypothalamic weights in the 1-d-old animals were 9-13 $\mathrm{mg}$ and increased to adult values by $28 \mathrm{~d}$.

Tissue was homogenized in 9 vol Tris-sucrose containing $100 \mathrm{mM}$ DTT. Details of the tissue preparation and incubation procedures have been reported (6). In some experiments, a high-speed pellet (material sedimenting between 1,000 and $160,000 \mathrm{~g}$ ) was prepared as described (6), and resuspended to the original homogenate volume. $90 \mu$ l of the homogenates were incubated in triplicate at $37^{\circ} \mathrm{C}$ under nitrogen for $2 \mathrm{~h}$ with $10 \mu l$ substrate solution, giving concentrations in the incubation mixtures of $\simeq 0.2 \mathrm{nM}{ }^{125} \mathrm{I}_{-1} \mathrm{~T}_{4}(40,000 \mathrm{cpm})+\simeq 0.1 \mathrm{nM}$ ${ }^{[131} I^{1} T_{3}(20,000 \mathrm{cpm})$ and either $1 \mu \mathrm{M}$ nonradioactive $\mathrm{T}_{3}$ or $1 \mu \mathrm{M}$ nonradioactive $\mathrm{rT}_{3}$. Endogenous $\mathrm{T}_{4}$ and $\mathrm{T}_{3}$ contribute $\sim 0.15 \mathrm{nM}$ each to the concentrations in the incubation mixtures (11). Variations in tracer $T_{4}$ and $T_{3}$ concentrations between $0.1 \mathrm{nM}$ and $1 \mathrm{nM}$ do not affect fractional degradation rates. Hypothalamic homogenates from 1-d-old rats were incubated only with $1 \mu \mathrm{M} \mathrm{T} \mathrm{T}_{3}$ because of the small amount of tissue available. Other homogenates were incubated with $1 \mu \mathrm{M} \mathrm{T}_{3}$ and, separately, with $1 \mu \mathrm{M} \mathrm{rT}_{3} . \mathrm{T}_{3}$ inhibits 5-deiodination, but not $5^{\prime}$-deiodination, of $\mathrm{T}_{4}$ and inhibits degradation of newly formed $\mathrm{T}_{3}(6)$. $\mathrm{rT}_{3}$ inhibits $\mathrm{T}_{4} 5^{\prime}$-deiodination but not $\mathrm{T}_{4}$ or $\mathrm{T}_{3}$ 5-deiodination (6). The data from incubations with $1 \mu \mathrm{M} \mathrm{rT}_{3}$ thus show maximal $\mathrm{T}_{4}$ 5-deiodination rates, not inhibited by $\mathrm{T}_{3}$.

Incubations were terminated by the addition of $200 \mu \mathrm{l}$ ethanol and $50 \mu \mathrm{l}$ of $0.04 \mathrm{~N} \mathrm{NaOH}$ containing nonradioactive $\mathrm{L}-\mathrm{T}_{3}+\mathrm{L}-\mathrm{T}_{4}+$ methimazole (6). The ethanolic extracts were analyzed by descending paper chromatography in t-amyl alcohol:hexane:ammonia, 5:1:6. Further details of the analytical methods and calculations have been published (6). Identifiable products of $T_{4}$ degradation were $T_{3}, r T_{3}, 3,3^{\prime}-T_{2}$, and $\mathrm{I}^{-}$. Identifiable products of $\mathrm{T}_{3}$ degradation were $3,3^{\prime}-\mathrm{T}_{2}, 3^{\prime}-\mathrm{L}$ iodothyronine $\left(3^{\prime}-\mathrm{T}_{1}\right)$, and $\mathrm{I}^{-}$. Results are expressed as percent ${ }^{125} \mathrm{I}-\mathrm{T}_{4}$ or $\left[{ }^{131} \mathrm{I}\right] \mathrm{T}_{3}$ converted to the various products. In all $\mathrm{ex}-$ periments reported here, excess $\mathrm{I}^{-}$production (6) amounted to $\leq 5 \%$ of ${ }^{125} \mathrm{I}_{-} \mathrm{T}_{4}$ and $<2 \%$ of $\left[{ }^{131} \mathrm{I}\right] \mathrm{T}_{3}$. Experimental protocols always included 0 time and 2 -h control incubations with no tissue in the buffer. Reaction rates in the presence of tissue were corrected for nonenzymatic reactions observed in the buffer controls. Boiled tissue controls were not appropriate owing to the occurrence of nonenzymatic deiodination of $T_{4}$ without $\mathrm{T}_{3}$ or $\mathrm{rT}_{3}$ production (6). In the buffer control incubations, $<5 \%$ of $\mathrm{T}_{4}$ was degraded, $<5 \%$ of $\mathrm{T}_{3}$ was degraded, and $\mathrm{T}_{3}$ production from $\mathrm{T}_{4}$ was $<1.5 \%$. Protein was measured by the method of Lowry et al. (12), after DTT was removed by perchloric acid precipitation of the protein (6).

In the statistical analyses, each mean of triplicate incubations within an experiment was treated as a single value. When data were not normally distributed or variances were not homogeneous, nonparametric statistics were used. To compare reaction rates at different ages, overall significance was tested by Kruskal-Wallis one-way analysis of variance (13). If the $\chi^{2}$ was significant, comparisons of rates at different ages were made by the Mann-Whitney test (13), if three or more values were present. All the values for rats $60 \mathrm{~d}$ or older were grouped together, inasmuch as no measurement varied with age within this group. Also, inter-experiment variation of adult results was found not to differ from intra-experiment adult results when tissues from individual rats were prepared separately. Inter-experiment variation, therefore, seems largely to reflect biological variation. Values for 4 -d-old and 7 -d-old rats 
and for 41-48-d-old rats were grouped together to minimize the data sets with $n<3$. This grouping does not materially affect the conclusions.

\section{RESULTS}

$T_{4} 5^{\prime}$-deiodination in homogenates of cerebrum, cerebellum, and hypothalamus from 1-d-old and adult rats (Table I). The net production rate of $\left[{ }^{125} \mathrm{I}\right] \mathrm{T}_{3}$ in 1-d cerebral homogenates was similar to the rate in adult cerebral homogenates. Degradation of $\left[{ }^{131} \mathrm{I}\right] \mathrm{T}_{3}$ and removal of ${ }^{125} \mathrm{I}-\mathrm{T}_{4}$ by conversion to $\mathrm{rT}_{3}$ were more rapid in the cerebral homogenates from neonates than in those from adults (Table I, lines 2 and 5). Net production of $\left[{ }^{125} \mathrm{I}\right] 3,3^{\prime}-\mathrm{T}_{2}$ was $2.50 \pm 0.5$ (SE)\% of added $\mathrm{T}_{4}$ in 1-d cerebral homogenates and not detectable in adult cerebral homogenates. These findings suggested that the capacity for $T_{4}$ to $T_{3}$ conversion might be greater in neonatal cerebral tissue than in adult cerebral tissue.

In 1-d rats, net production of $\mathrm{T}_{3}$ was not detectable in cerebellar and hypothalamic homogenates. Net production of [ $\left.{ }^{125} \mathrm{I}\right] 3,3^{\prime}-\mathrm{T}_{2}$ from ${ }^{125} \mathrm{I}-\mathrm{T}_{4}$ was also very low or undetectable $(<1 \%$ conversion) in incubations of cerebellar and hypothalamic homogenates from 1-d-old rats; therefore, the possibility can be excluded that substantial quantities of $\mathrm{T}_{3}$ were produced and rapidly degraded. Even considering the differences between the age groups in homogenate protein content (Table I), and in rates of $\mathrm{T}_{4}$ depletion via 5-deiodination (see below), the capacities of neonatal cerebellar and hypothalamic homogenates to catalyze $T_{4} 5^{\prime}$-deiodination were clearly much lower than those of the correspond- ing adult homogenates. In homogenates from adult rats, the mean $T_{4} 5^{\prime}$-deiodination rate was highest in cerebellar tissue (Table I), $P<0.001$ vs. cerebrum and hypothalamus.

Tyrosyl ring deiodination of $T_{4}$ and $T_{3}$ in cerebrum, cerebellum, and hypothalamus from 1-d-old and adult rats (Table I). The mean rates of tyrosyl ring deiodination of $T_{4}$ and $T_{3}$ were more than three times as great in cerebral homogenates from 1-d-old rats than in adult cerebral homogenates in incubations with $1 \mu \mathrm{M} \mathrm{T}_{3}$. In incubations using $1 \mu \mathrm{M} \mathrm{rT}_{3}$ instead, $61 \pm 6 \%$ of $\mathrm{T}_{4}$ was converted to $\mathrm{rT}_{3}$ in the 1-d homogenates vs. $33 \pm 3 \%$ in the adult homogenates $(P<0.001)$. In cerebellar homogenates from 1-d-old rats (Table I), tyrosyl ring deiodination rates of $T_{4}$ and $T_{3}$ were about half the rates in 1-d cerebral homogenates, but were much greater than the rates in adult cerebellar homogenates, the latter having very little activity. In cerebellar incubations with $1 \mu \mathrm{M} \mathrm{rT}_{3}$, similar findings were noted: $\mathrm{T}_{4}$ to $\mathrm{rT}_{3}$ conversion was $41.4 \pm 3 \%$ in the 1 - $\mathrm{d}$ homogenates and $1.1 \pm 0.3 \%$ in adult homogenates $(P<0.001)$. In hypothalamic homogenates from 1-d-old rats (Table I), tyrosyl ring deiodination rates of $T_{4}$ and $T_{3}$ were the highest of all the tissues tested, whereas rates in the adult hypothalamic homogenates were similar to the rates in adult cerebral homogenates.

To test the effects of differences in protein content on tyrosyl ring deiodination rates, tyrosyl ring deiodination of $1 \mu \mathrm{M} \mathrm{T}_{3}$ was measured in adult tissue homogenates diluted with 1 vol Tris-sucrose- $100 \mathrm{mM}$ DTT. In the three brain regions, rates were reduced in the diluted homogenates to $42-76 \%$ of the rates in

TABLE I

Iodothyronine Deiodination in Cerebral, Cerebellar, and Hypothalamic Homogenates from 1-d-old and Adult Rats

\begin{tabular}{|c|c|c|c|c|c|c|}
\hline \multirow[b]{2}{*}{ Measurement } & \multicolumn{2}{|c|}{ Cerebrum } & \multicolumn{2}{|c|}{ Cerebellum } & \multicolumn{2}{|c|}{ Hypothalamus } \\
\hline & $1 \mathrm{~d}$ & Adult & $1 \mathrm{~d}$ & Adult & $1 \mathrm{~d}$ & Adult \\
\hline $\begin{array}{l}T_{4} 5^{\prime} \text {-deiodination } \\
\left.\quad \text { (percent } T_{4} \text { converted to } T_{3}\right)\end{array}$ & $9.9 \pm 2.5$ & $8.9 \pm 1.2$ & $0.4 \pm 0.4^{*}$ & $17.6 \pm 1.6$ & $0.2 \pm 0.2^{*}$ & $7.6 \pm 1.0$ \\
\hline $\begin{array}{l}\mathrm{T}_{4} \text { 5-deiodination } \\
\quad\left(\text { percent } \mathrm{T}_{4} \text { converted to } \mathrm{r}_{3}\right)\end{array}$ & $20.8 \pm 1.7^{*}$ & $5.6 \pm 2.3$ & $10.4 \pm 1.7^{*}$ & $0.3 \pm 0.5$ & $46.2 \pm 7.5^{*}$ & $7.2 \pm 1.2$ \\
\hline $\begin{array}{r}T_{3} \text { tyrosyl deiodination } \\
\text { (percent added } T_{3} \text { ) }\end{array}$ & & & & & & \\
\hline $\begin{array}{l}3,3^{\prime}-\mathrm{T}_{2} \\
3^{\prime}-\mathrm{T}_{1} \\
3,3^{\prime}-\mathrm{T}_{2}+3^{\prime}-\mathrm{T}_{1}\end{array}$ & $\begin{array}{r}27.6 \pm 3.2^{*} \\
6.8 \pm 2.1^{*} \\
34.4 \pm 3.8^{*}\end{array}$ & $\begin{array}{r}9.6 \pm 1.3 \\
1.0 \pm 0.2 \\
10.6 \pm 1.4\end{array}$ & $\begin{array}{r}13.3 \pm 2.9^{*} \\
2.8 \pm 0.5^{*} \\
16.1 \pm 2.7^{*}\end{array}$ & $\begin{array}{l}0.3 \pm 0.2 \\
0.0 \pm 0.1 \\
0.3 \pm 0.3\end{array}$ & $\begin{array}{l}34.3 \pm 1.0^{*} \\
17.7 \pm 3.3^{*} \\
52.0 \pm 3.8^{*}\end{array}$ & $\begin{array}{l}8.2 \pm 1.4 \\
1.1 \pm 0.3 \\
9.3 \pm 1.6\end{array}$ \\
\hline Protein content, $m g / m l$ & $5.3 \pm 0.5$ & $6.8 \pm 0.5$ & $5.9 \pm 1.7 \ddagger$ & $10.0 \pm 0.5$ & $5.6 \pm 1.0 \ddagger$ & $8.6 \pm 0.5$ \\
\hline
\end{tabular}

Results are mean \pm SEM of individual experimental means for 60-100-d-old adult rats (12 experiments) and 1-d-old neonatal rats (three experiments). Incubations were performed at $37^{\circ} \mathrm{C}$ for $2 \mathrm{~h}$ with $\left.0.2 \mathrm{nM}^{125} \mathrm{I}_{-} \mathrm{T}_{4}+0.1 \mathrm{nM}^{131} \mathrm{I}\right] \mathrm{T}_{3}$ $+1 \mu \mathrm{M}\left[{ }^{127} \mathrm{I}_{3} \mathrm{~T}_{3}+100 \mathrm{mM}\right.$ DTT. Values for neonatal and adult tissues were compared using the $t$ test with $n=$ number of experiments. No correction was made for degradation of newly formed $\left[{ }^{125} \mathrm{I}^{\mathrm{T}} \mathrm{T}_{3}\right.$ or ${ }^{125} \mathrm{I}-\mathrm{rT}_{3}$.

$* P<0.001$.

$\$ P<0.01$ vs. adult tissue from the same region. 
corresponding undiluted homogenates. Correction for the differences in homogenate protein content would therefore magnify the differences between neonates and adults in tyrosyl ring deiodination rates seen in Table I, but would not greatly alter the comparison between the different regions.

Changes in $T_{4} 5^{\prime}$-deiodination rates during maturation. $\mathrm{T}_{4} 5^{\prime}$-deiodination rates (Figs. 1A, 2A, and 3A) increased after $7 \mathrm{~d}$, and exceeded adult rates between 14 and $35 \mathrm{~d}$ in cerebral and cerebellar homogenates and at 28 and $35 \mathrm{~d}$ in hypothalamic homogenates. The mean rates at the peak ages were two to three times the mean adult rates. $T_{3}$ production rates in the period 14-48 d could be compared directly to adult rates since there were no significant differences in $\mathrm{T}_{4}$ depletion and $T_{3}$ degradation (see below) or homogenate protein content.

\section{CEREBRAL HEMISPHERES}

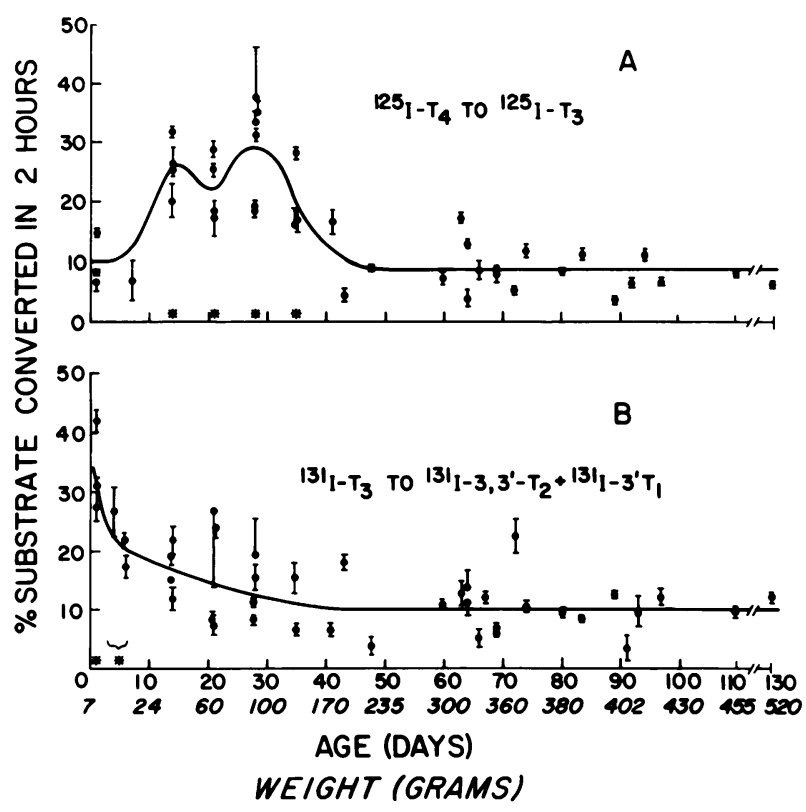

FIgURE $1 \quad \mathrm{~T}_{4} 5^{\prime}$-deiodination and $\mathrm{T}_{3}$ tyrosyl ring deiodination in homogenates of rat cerebral hemispheres. Each point is the mean $\pm S D$ of triplicate incubations using pooled tissues from three to four rats. Incubations were carried out at $37^{\circ} \mathrm{C}$ under $\mathrm{N}_{2}$ for $2 \mathrm{~h}$ in the presence of $\simeq 0.2 \mathrm{nM}^{125} \mathrm{I}^{-\mathrm{T}_{4}}+\simeq 0.1$ $\mathrm{nM}\left[{ }^{131} \mathrm{I}\right] \mathrm{T}_{3}+1 \mu \mathrm{M}\left[{ }^{127} \mathrm{I}\right] \mathrm{T}_{3}+100 \mathrm{mM}$ DTT. Asterisks indicate ages at which rates are significantly different $(P<0.05$ or less) from the rates in the adult rats $(60 \mathrm{~d}$ and older) by the Mann-Whitney test. Values for weights, in italics below the abcissa, are average weights of male rats at the indicated ages. The curves are drawn through the mean rates for ages with multiple points. (A) Net conversion of ${ }^{125} \mathrm{I}_{-} \mathrm{T}_{4}$ to $\left[{ }^{125} \mathrm{I}\right]-$ $\mathrm{T}_{3}$ in $2 \mathrm{~h}$. No correction was made for [ $\left.{ }^{125} \mathrm{I}\right] \mathrm{T}_{3}$ degradation. (B) Conversion of $\left.{ }^{[131} I\right] T_{3}$ to $\left[{ }^{131} I\right] 3,3^{\prime}-T_{2}+\left[{ }^{131} I\right] 3^{\prime}-T_{1}$. For technical reasons, only $\mathrm{T}_{3}$ deiodination could be measured in the $4 \mathrm{~d}$ incubations. More detailed analysis of the 1-d and adult incubations is given in Table I.

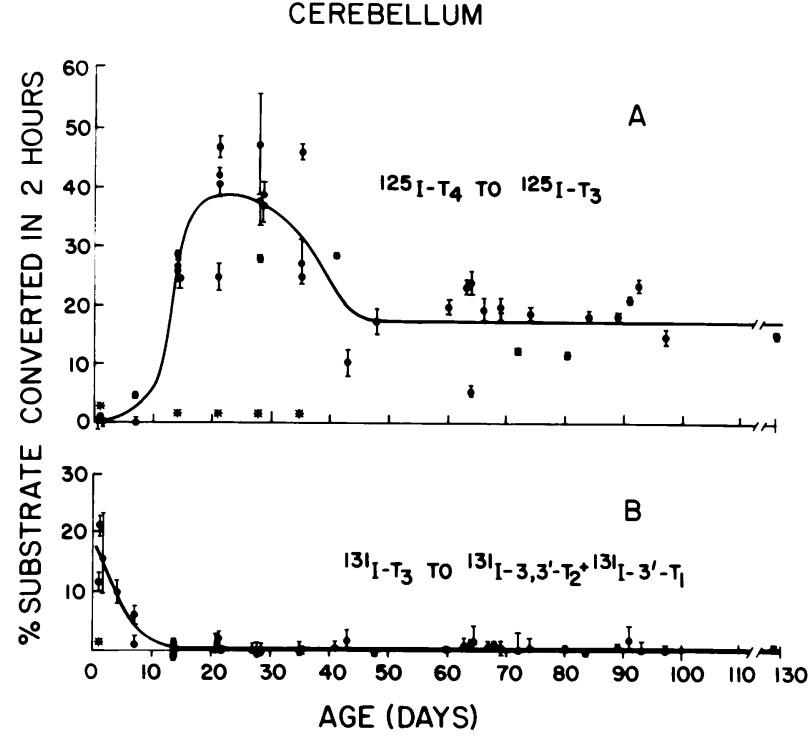

FIGURE $2 \mathrm{~T}_{4} 5^{\prime}$-deiodination and $\mathrm{T}_{3}$ tyrosyl ring deiodination in homogenates of rat cerebellum. Experimental details are given in the legend to Fig. 1.

Because of the remaining uncertainty about the relative $\mathrm{T}_{4} 5^{\prime}$-deiodinase activities in the 1 -d and adult cerebral homogenates, and because the peak rates seen between 14 and $35 \mathrm{~d}$ could result from changes in either the Michaelis constant $\left(K_{m}\right)$ for $\mathrm{T}_{4}$ or maximum enzyme activity $\left(V_{\max }\right)$, or both, we performed $T_{4}$ doseresponse experiments. Cerebral homogenates from 1-, 28-d-old and adult rats were incubated for $2 \mathrm{~h}$ with $2 \mu \mathrm{M} \mathrm{T}_{3}$ (instead of $1 \mu \mathrm{M}$ ) and with $0.2,2,5,10$, and 20 $\mathrm{nM} \mathrm{T} \mathrm{T}_{4}$. There was a progressive decrease in all the

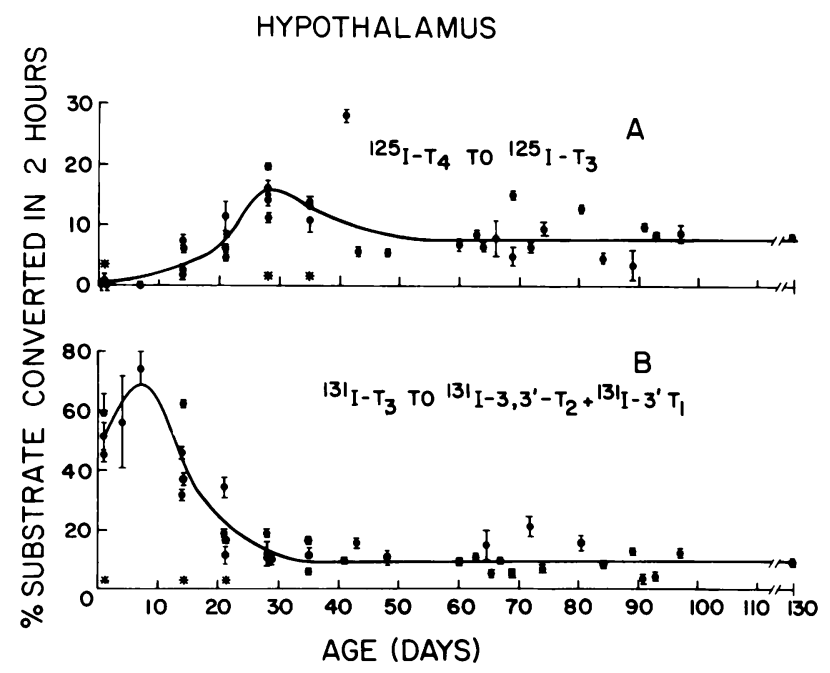

FIGURE $3 \quad T_{4} 5^{\prime}$-deiodination and $T_{3}$ tyrosyl ring deiodination in homogenates of rat hypothalamus. Experimental details are given in the legend to Fig. 1. 
homogenates in percent conversion of ${ }^{125} \mathrm{I}-\mathrm{T}_{4}$ to $\left[{ }^{125} \mathrm{I}\right]-$ $T_{3}$ as the $T_{4}$ concentration was increased, but when rates were translated from percent conversion to femtomoles $T_{3}$ produced per minute per milligram protein, the molar reaction rates were found to increase with the $T_{4}$ concentration. In these incubations the extent of $\left[{ }^{131} \mathrm{I}\right] \mathrm{T}_{3}$ degradation was reduced to $6-15 \%$, the extent of $\mathrm{T}_{4}$ degradation (largely to $\mathrm{rT}_{3}$ ) was reduced to $16-25 \%$ (compare Table I), and the protein concentrations were similar in the homogenates from the pups and the adults. The higher $T_{3}$ concentration thus facilitated comparisons of $\mathrm{T}_{4} 5^{\prime}$-deiodination rates. EadieHofstee plots of (reaction rate $\div$ average $\mathrm{T}_{4}$ concentration) vs. molar reaction rate (14) were linear. The kinetic parameters calculated from the plots are given in Table II. The apparent $K_{\mathrm{m}}$ for $\mathrm{T}_{4}$ was $34 \%$ lower in the 1-dold rats than in adults, whereas it was $45 \%$ higher in the 28-d-old rats than in adults. The $\mathrm{V}_{\max }$ was not significantly different in the 1-d-old and adult rats, but the $V_{\max }$ in the $28 \mathrm{~d}$ rats was considerably higher than in other groups, 2.6 times as high as that of the adult rats.

Changes in $T_{3}$ tyrosyl ring deiodination rates during maturation. Total $\mathrm{T}_{3}$ tyrosyl ring deiodination rates (Figs. 1B, 2B, and 3B) declined progressively with age, attaining adult values at $14 \mathrm{~d}$ for cerebrum and cerebellum and at $28 \mathrm{~d}$ for hypothalamus. In parallel incubations, using $<1 \mathrm{nM} \mathrm{T}_{3}$, fractional $\mathrm{T}_{3}$ tyrosyl ring deiodination rates were too rapid $(>75 \%)$ in cerebral and hypothalamic homogenates at all ages to allow differences to be detected. However, in cerebellar homogenates incubated with $<1 \mathrm{nM} \mathrm{T}_{3}$, mean fractional $\mathrm{T}_{3}$ tyrosyl ring deiodination fell from $70 \%$ at $1 \mathrm{~d}$ to $6 \%$ at $14 \mathrm{~d}$ and remained at that level thereafter. These data show that adult cerebellum has real, but low level, tyrosyl ring deiodinase activity which becomes saturated at $1 \mu \mathrm{M} \mathrm{T}_{3}$.

The conversion of ${ }^{125} \mathrm{I}_{-} \mathrm{T}_{4}$ to $\mathrm{rT}_{3}$ in the presence of $1 \mu \mathrm{M} \mathrm{T}_{3}$ or $1 \mu \mathrm{M} \mathrm{rT}$ showed the same pattern of decrease with age as did total tyrosyl ring deiodination of $T_{3}$. That is, for each brain region, $T_{4}$ tyrosyl ring deiodination rates declined progressively from the high neonatal values (Table I) and reached adult levels at the same age as total $T_{3}$ tyrosyl ring deiodination.

TABLE II

Kinetic Parameters of $T_{4} 5^{\prime}$-deiodinase in Cerebral Homogenates

\begin{tabular}{lcc}
\hline Age & Apparent $K_{\mathrm{m}}$ for $\mathrm{T}_{4}$ & $\mathrm{~V}_{\max }$ \\
\hline$n M$ & $\begin{array}{c}\text { fmol } T_{3} \text { per min } \\
\text { per } m g \text { protein }\end{array}$ \\
$1 \mathrm{~d}$ & $9.5(9.2,9.9)$ & $2.3(2.0,2.9)$ \\
$28 \mathrm{~d}$ & $21.0(17.4,26.4)$ & $3.9(3.8,4.1)$ \\
Adult & $14.3(12.9,16.1)$ & $1.5(1.0,2.4)$ \\
\hline
\end{tabular}

Values in parentheses are $95 \%$ confidence limits.

\section{DISCUSSION}

The present studies extend the information available about in vitro thyroid hormone metabolism in brain. From a methodological standpoint, routine inclusion of 1-2 $\mu \mathrm{M} \mathrm{L}-\mathrm{T}_{3}$ in the incubations greatly facilitated quantitation of $T_{4} 5^{\prime}$-deiodination, allowing initial estimates of kinetic parameters for $\mathrm{T}_{4} 5^{\prime}$-deiodinase in normal rat brain. In heterogenous homogenates such as those employed here, these parameters must be interpreted cautiously, because nonenzymatic binding of substrate can influence them greatly. They do have some value in comparing physically similar systems. With that in mind, the apparent $K_{\mathrm{m}}$ for $\mathrm{T}_{4}$ of $\mathrm{T}_{4} 5^{\prime}$-deiodinase in adult rat cerebral homogenates, $14 \mathrm{nM}$, was found to be very close to the apparent $K_{\mathrm{m}}$ for $\mathrm{T}_{4}$ of rat anterior pituitary homogenate $\mathrm{T}_{4} 5^{\prime}$-deiodinase, $8.8 \mathrm{nM}$ (15). Both of these values are 35-1,000-fold less than the $K_{\mathrm{m}}$ for $\mathrm{T}_{4}$ of rat liver and kidney homogenate $T_{4} 5^{\prime}$-deiodinases (16-23). From this kinetic evidence and from the responses of brain and anterior pituitary $T_{4} 5^{\prime}$-deiodinase activity in hyper- and hypothyroidism $(6,8,15)$, the suggestions may be drawn that the brain and anterior pituitary $\mathrm{T}_{4} 5^{\prime}$-deiodinases could be the same, or very similar, and that both may well be different from the liver and kidney $\mathrm{T}_{4} 5^{\prime}$-deiodinase (17).

The maturational pattern of $\mathrm{T}_{4} 5^{\prime}$-deiodinase activity in the brain proved to be complex. $\mathrm{T}_{4} 5^{\prime}$-deiodinase activity in homogenates of neonatal tissue was highest in the cerebrum and virtually absent in cerebellum and hypothalamus. In all three regions, the $T_{4} 5^{\prime}$ deiodination rates increased over the first $4 \mathrm{wk}$ of life, attaining peaks above adult values, then declining to adult rates. For the cerebrum, this peak reflected an increase in the total enzyme activity $\left(\mathrm{V}_{\max }\right)$; the modest difference in apparent $K_{\mathrm{m}}$ for $\mathrm{T}_{4}$ in the 28-d-old vs. adult rats was in a direction that would tend to lower rates in the 28-d-old rats at tracer $T_{4}$ concentrations. The quantitative differences between regions at all ages reinforce our previous findings of regional diversity of $T_{4} 5^{\prime}$-deiodinase activity (6).

Other tissues show different developmental patterns. In rat anterior pituitary tissue, $T_{4} 5^{\prime}$-deiodination rate in vitro are elevated in the neonatal period, after $1 \mathrm{~d}$, and decline to adult values by $28-45 \mathrm{~d}(8,9)$. In rat liver homogenates, $T_{4} 5^{\prime}$-deiodination rates are much lower in fetal and neonatal tissue than in adult tissue $(7,8)$ but the differences between neonatal and adult liver are lessened or abolished by DTT supplementation $(7,8)$. There is some uncertainty about the time course of change of $T_{4} 5^{\prime}$-deiodinase activity in liver: Harris et al. (24) found normalization of rates in liver homogenates at $5 \mathrm{~d}$ with (24) or without (7) a peak above adult rates at $7 \mathrm{~d}$, whereas we observed persistently low rates at $9 \mathrm{~d}$ and normal adult rates at $21 \mathrm{~d}(8)$. 
For iodothyronine tyrosyl ring deiodination, the pattern of changes was completely different. Hypothalamic tissue showed the highest rates initially and remained above adult values longest. In all three tissues, there was a progressive decline in iodothyronine tyrosyl ring deiodinase activity until a plateau was reached at the adult values. Tanaka et al. (25) have reported in preliminary form that $T_{4}$ and $T_{3}$ tyrosyl ring deiodination is more rapid in homogenates of fetal rat brain than in homogenates of adult rat brain. Their observations are in accord with ours. The parallel changes of $T_{4}$ tyrosyl ring deiodination and $T_{3}$ tyrosyl ring deiodination in these and previous experiments (6) leave little doubt that a single brain tyrosyl ring deiodinase accepts $T_{4}$ and $T_{3}$ as substrates. In contrast, the present results support our previous conclusion (6) that the brain tyrosyl ring deiodinase is not the same enzyme as the $T_{4} 5^{\prime}$-deodinase: neonatal hypothalamic homogenates have abundant tyrosyl ring deiodinase activity and are devoid of $\mathrm{T}_{4} 5^{\prime}$-deiodinase activity (Table I), whereas cerebellar homogenates from hypothyroid adult rats have abundant $\mathrm{T}_{4} 5^{\prime}$ deiodinase activity and are devoid of iodothyronine tyrosyl ring deiodinase activity (6). Rat liver and monkey hepatocarcinoma cells contain iodothyronine tyrosyl ring deiodinases with catalytic properties generally similar to the rat brain enzyme (26-28), and adult rat liver has higher activity than neonatal rat brain $(26,27)$. Nonetheless, complete physical separation of hepatic phenolic and tyrosyl ring deiodinase activities has not been achieved (29). Our findings in brain homogenates lead us to predict that hepatic phenolic and tyrosyl ring deiodinases will prove to be separate molecules.

By analogy with observations concerning $T_{4}$ to $T_{3}$ conversion in the anterior pituitary, we have reasoned that local $\mathrm{T}_{3}$ production in the brain is likely to be physiologically significant (6). A recent preliminary report indicates that after ${ }^{125} \mathrm{I}-\mathrm{T}_{4}$ injection, the fraction of injected radioactivity that appears as $T_{3}$ is greater in brain extracts from hypothyroid rats than in extracts from normal rats (30). This finding is in agreement with our data that in vitro $T_{4} 5^{\prime}$-deiodinase activity is much greater in cerebral cortex and cerebellum of hypothyroid adult rats than in normal tissue (6). The coherent patterns of change in activities of both deiodinases in brain tissue during maturation reinforce the idea that these enzymes may have an important role in the expression of thyroid hormone effects. An obvious possibility is that the balance of intracellular $\mathrm{T}_{3}$ production and $\mathrm{T}_{3}$ degradation is a major determinant of steady state $T_{3}$ tissue concentrations. It is difficult to relate the in vivo data of Vigoroux et al. (5), to the present results, since they extracted whole brains and since in vitro $T_{3}$ production and $T_{3}$ degradation rates at $10 \mathrm{~d}$ are changing rapidly and in opposite direc- tions. The data in Figs. 1-3 suggest that 1-7, 28 and $>60 \mathrm{~d}$ would be more suitable ages at which to compare brain tissue levels of iodothyronines and in vivo iodothyronine metabolism to obtain further direct evidence of the physiological significance of the iodothyronine metabolic pathways observed in vitro.

These studies, together with previous reports, suggest that there is a complex system of local regulation of thyroid hormone metabolism in target tissues, serving to modulate the expression of thyroid hormone effect. Many other factors that may regulate thyroid hormone secretion and actions on target tissues undergo changes in the first several weeks of life in the rat. These include the number of $T_{3}$ nuclear receptors in different brain regions and in the liver, the sensitivity of thyrotropin secretion to thyrotropinreleasing hormone and to circulating iodothyronine concentrations, the plasma activity of the proteases that degrade thyrotropin-releasing hormone, the sensitivity of the thyroid gland to inhibition of secretion by iodide, and the sensitivity of the liver to plasma $T_{3}$ concentrations (31-39). Much additional work will be required to integrate these diverse observations into a complete picture of the regulation of thyroid hormone action in the developmental period.

\section{ACKNOWLEDGMENTS}

We thank Dr. Ray Gleason for advice in the statistical analyses, Dr. Reed Larsen for helpful discussions and valuable ideas, and Ms. Melissa Jones for expert manuscript preparation.

This work was supported in part by Biomedical Research Support Grant SO7 RRO 5489 from the Division of Research Resources, and grant 1-RO1-AM 25340 01A1, National Institutes of Health.

\section{REFERENCES}

1. Obregon, M. J., F. Roelfsema, G. Morreale de Escobar, F. Escobar del Rey, and A. Querido, 1979. Exchange of triiodothyronine derived from thyroxine with circulating triiodothyronine as studied in the rat. Clin. Endocrinol. (Oxf.) 10: 305-315.

2. Crantz, F. R., and P. R Larsen. 1980. Rapid thyroxine to $3,5,3^{\prime}$-triiodothyronine $\left(T_{3}\right)$ conversion and nuclear $\mathrm{T}_{3}$ binding in rat cerebral cortex and cerebellum. J. Clin. Invest. 65: 935-938.

3. Crantz, F. R., and P. R. Larsen. 1980. Contribution of local thyroxine to $3,5,3^{\prime}$-triiodothyronine $\left(T_{3}\right)$ conversion to nuclear $\mathrm{T}_{3}$ in rat cerebral cortex and cerebellum. Clin. Res. 28: 478A (Abstr.).

4. Dratman, M. B., and F. L. Crutchfield. 1978. Synaptosomal $\left({ }^{125} \mathrm{I}\right)$ triiodothyronine after intravenous $\left({ }^{125} \mathrm{I}\right)$ thyroxine. Am. J. Physiol. 235: E638-E647.

5. Vigouroux E., J. Clos, and J. Legrand. 1979. Uptake and metablism of exogenous and endogenous thyroxine in the brain of young rats. Horm. Metab. Res. 11: 228-232.

6. Kaplan, M. M., and K. A. Yaskoski. 1980. Phenolic and tyrosyl ring deiodination of iodothyronines in rat brain homogenates. J. Clin. Invest. 66: 551-562.

7. Harris, A. R. C., S. L. Fang, L. Hinerfeld, L. E. Braverman, and A. G. Vagenakis. 1979. The role of sulfydryl groups on the impaired hepatic 3,3',5-triiodothyronine 
generation from thyroxine in the hypothyroid, starved, fetal and neonatal rodent. J. Clin. Invest. 63: 516-524.

8. Cheron, R. G., M. M. Kaplan, and P. R. Larsen. 1980. Divergent changes of thyroxine $5^{\prime}$-monodeiodination in rat pituitary and liver during maturation. Endocrinology. 106: 1405-1409.

9. El Zaheri, M. M., L. E. Braverman, and A. G. Vagenakis 1980. Enhanced conversion of thyroxine to triiodothyronine in the neonatal rat pituitary. Endocrinology. 106: 1735-1739.

10. Glowinski, J., and L. L. Iversen. 1966. Regional studies of catecholamine metabolism in the rat brain-I. The disposition of $\left[{ }^{3} \mathrm{H}\right]$ norepinephrine, $\left[{ }^{3} \mathrm{H}\right]$ dopamine and $\left[{ }^{3} \mathrm{H}\right]$ DOPA in various regions of the brain. J. Neurochem. 13: 655-669.

11. Heninger, R. W., F. C. Larson, and E. C. Albright. 1963. Iodine-containing compounds of extrathyroidal tissues. J. Clin. Invest. 42: 1761-1768.

12. Lowry, O. H., N. J. Rosebrough, A. L. Farr, and R. J. Randall. 1951. Protein measurement with the Folin phenol reagent. J. Biol. Chem. 193: 265-275.

13. Mosteller, F., and R. E. K. Rourke, 1973. Sturdy Statistics. Addison-Wesley Publishing Co., Reading, Mass. 210-223.

14. Segel, I. H. 1975. Enzyme kinetics. Behaviour and analysis of rapid equilibrium and steady enzyme systems. John Wiley and Sons, New York. 214.

15. Kaplan, M. M. 1980 . Thyroxine $5^{\prime}$-monodeiodination in rat anterior pituitary homogenates. Endocrinology. 106: 567-576.

16. Visser, T. J., I. van Does-Tobe, R. Docter, and G. Hennemann. 1975. Conversion of thyroxine into triiodothyronine by rat liver homogenate. Biochem. J. 50: 489-493.

17. Kaplan, M. M., J. B. Tatro, R. Breitbart, and P. R. Larsen. 1979. Comparison of thyroxine and $3,3^{\prime}, 5^{\prime}$-triiodothyronine metabolism in rat kidney and liver homogenates. Metab. Clin. Exp. 28: 1139-1146.

18. Kaplan, M. M., and R. D. Utiger. 1978. Iodothyronine metabolism in rat liver homogenates. J. Clin. Invest. 61: 459-471.

19. Hüfner, M., M. Grussendorf, and M. Ntokalou. 1977 Properties of the thyroxine $\left(\mathrm{T}_{4}\right)$ monodeiodinating system in rat liver homogenate. Clin. Chim. Acta. 78: 251-259.

20. Chopra, I. J. 1977. A study of extrathyroidal conversion of thyroxine $\left(\mathrm{T}_{4}\right)$ to $3,3^{\prime}, 5$-triiodothyronine in vitro. Endocrinology. 101: 453-463.

21. Chiraseveenuprapund, P., U. Buergi, A.Goswami, and I. N. Rosenberg. 1978. Conversion of L-thyroxine to triiodothyronine in rat kidney homogenate. Endocrinology. 102: 612-622.

22. Leonard, J. L., and I. N. Rosenberg. 1980. Iodothyronine 5 -deiodinase from rat kidney: substrate specificity and the 5'-deiodination of reverse triiodothyronine. Endocrinology. 107: 1376-1383.

23. Kaplan, M. M. 1979. Changes in the particulate subcellular component of hepatic thyroxine $5^{\prime}$-monodeiodinase in hyperthyroid and hypothryoid rats. Endocrinology. 105: 548-553.

24. Harris, A. R. C., S. L. Fang, J. Prosky, L. E. Braverman, and A. G. Vagenakis. 1978. Decreased outer ring monodeiodination of thyroxine and reverse triiodothyronine in the fetal and neonatal rat. Endocrinology. 103: 2216-2222.

25. Tanaka, K., H. Ishii, K. Naito, M. Nishikawa, and M. Inada.
1980. Inner ring monodeiodination of thyroxine $\left(T_{4}\right)$ and $3,5,3^{\prime}$-triiodothyronine $\left(\mathrm{T}_{3}\right)$ in fetal and adult rat brain. Program of the 62nd Annual Meeting of the Endocrine Society, Washington, D. C. 222 (Abstr.)

26. Gavin, L. A., F. Bui, F. McMahon, and R. R. Cavalieri. 1980. Sequential deiodination of thyroxine to $3,3^{\prime}$-diiodothyronine via 3,5,3'-triiodothyronine and 3,3',5'-triiodothyronine in rat liver homogenate. The effects of fasting versus glucose feeding. J. Biol. Chem. 254: 49-54.

27. Visser, T. J., D. Fekkes, R. Docter, and G. Hennemann. 1979. Kinetics of enzymic reductive deiodination of iodothyronines. Effect of pH. Biochem. J. 179: 489-495.

28. Sorimachi, K., and J. Robbins. 1977. Metabolism of thyroid hormones by cultured monkey hepatocarcinoma cells. Nonphenolic ring deiodination and sulfation. J. Biol. Chem. 252: 4458-4463.

29. Fekkes, D., E. Van Overmeeren, G. Hennemann, and T. J. Visser. 1980 Solubilization and partial characterization of rat liver iodothyronine deiodinases. Biochim. Biophys. Acta. 613: 41-51.

30. Dratman, M. B., and F. L. Crutchfield. 1980. Normally high levels of $T_{3}$ generated from $T_{4}$ in brain markedly increased by hypothyroidism: contrastingly minimal responses in other tissues. Program of the 62nd Annual Meeting of the Endocrine Society, Washington, D. C. 223 (Abstr.).

31. Valcana, T., and P. S. Timiras. 1978. Nuclear triiodothyronine receptors in the developing rat brain. Mol. Cell. Endocr. 11: 31-41.

32. Schwartz, H. L., and J. H. Oppenheimer. 1978. Ontogenesis of 3,5,3'-triiodothyronine receptors in neonatal rat brain: dissociation between receptor concentration and stimulation of oxygen consumption by 3,5,3'-triiodothyronine. Endocrinology. 103: 943-948.

33. Coulombe, P., J. Ruel, and J. H. Dussault. 1979. Analysis of nuclear 3,5,3'-triiodothyronine binding capacity and tissue response in the liver of the neonatal rat. Endocrinology. 105: 952-959.

34. Tonooka, N., and M. A. Greer. 1978. Evidence that control of fetal thyrotropin secretion is independent of both the fetal and maternal hypothalamus. Endocrinology. 102: 852-858.

35. Theodoropoulos, T., L. E. Braverman, and A. G. Vagenakis. 1979. Thyrotropin-releasing hormone is not required for thyrotropin secretion in the perinatal rat. J. Clin. Invest. 63: 588-594.

36. Strbak, V., and M. A. Greer. 1979. Acute effects of hypothalamic ablation on plasma thyrotropin and prolactin concentrations in the suckling rat: evidence that early postnatal pituitary regulation is independent of hypothalamic control. Endocrinology. 105: 488-492.

37. Walker, P., G. Verret, P. Coulombe, and J. H. Dussault. 1978. Effects of triiodothyronine $\left(\mathrm{T}_{3}\right)$ on the thyrotropinreleasing hormone (TRH) induced thyrotropin (TSH) release in the neonatal rat. Program of the 54th meeting of the American Thyroid Association, Portland, Ore. T-15 (Abstr.).

38. Neary, J. T., J. D. Kieffer, P. Federico, H. Mover, F. Maloof, and M. Soodak. 1976. Thyrotropin-releasing hormone: development of inactivation system during maturation of the rat. Science (Wash. D. C.) 193: 403-405.

39. Theodoropoulos, T., L. E. Braverman, and A. G Vagenakis. 1979. Iodide induced hypothyroidism: A potential hazard during perinatal life. Science(Wash. D. C.) 205: 502-503. 